\title{
The challenge of finding high grain yield and pre-harvest sprouting tolerant genotypes in Brazilian wheat germplasm
}

\author{
Rafael Nornberg ${ }^{* 1}$, Henrique de Souza Luche ${ }^{1}$, José Antonio Gonzalez da Silva ${ }^{2}$, Cristiano Mathias \\ Zimmer $^{1}$, Francieli Fatima Cima ${ }^{1}$, Mateus Olivo ${ }^{1}$, Antonio Costa de Oliveira ${ }^{1}$
}

${ }^{1}$ Eliseu Maciel School of Agronomy, Plant Genomics and Breeding Center, Federal University of Pelotas (UFPel), Gomes Carneiro Street 01, 96010-900, RS, Pelotas, Brazil

${ }^{2}$ School of Agronomy, Department of Agrarian Studies, Regional University of Northwest of Rio Grande do Sul State (UNIJUÍ), Comércio Street 300, 98700-000, RS, Ijuí, Brazil

*Corresponding author: rafaelnornberg@yahoo.com.br

\begin{abstract}
Pre-harvest sprouting (PHS) harms the quality of wheat by converting starch into sugar and decreasing the flour quality. Therefore, improving wheat genotypes for PHS is critical for Brazilian wheat breeding programs. The goals of this study were to evaluate the combining ability and heterosis of Brazilian wheat genotypes, aiming to increase genetic gains and to identify promising combinations capable of generating superior genotypes for grain yield and pre-harvest sprouting tolerance. The work was conducted in 2011 in Capão do Leão, RS, Brazil, under an experimental design of randomized blocks with three repetitions. The traits of eight parents and 56 wheat hybrids linked to pre-harvest sprouting and grain yield were evaluated. The presence of additive and nonadditive gene effects and maternal effects controlling pre-harvest sprouting tolerance in Brazilian wheats were observed in some combinations. The cultivars BRS 194, Frontana and Quartzo when used as parents contributed with additive and non-additive gene effects for pre-harvest sprouting tolerance in wheat. The parental Quartzo contributes with genes of additive and non-additive effects in the increase of grain yield. Combinations which include BRS 194, Frontana and Quartzo show effective ability of recovering high yield genotypes with pre-harvest sprouting tolerance.
\end{abstract}

Keywords: ability combination, falling number, heterosis, Triticum aestivum $\mathrm{L}$.

Abbreviations: PHS_pre-harvest sprouting; ABA_abscisic acid; GA_gibberellic acid; SG_percentage of sprouted grains; WFN_wet falling number; BOD_biological oxygen demand; GY_grain yield per plant; GCA_general combining ability; SCA_specific combining ability.

\section{Introduction}

In wheat (Triticum aestivum L.), pre-harvest sprouting (PHS) of physiologically mature grains in the ear is an important factor influencing the reduction of grain yield and flour quality (Rasul et al., 2012; Kulwal et al., 2012). In Brazil, conditions of rainfall and high temperatures during ripening of wheat may cause PHS and reduce grain quality (Bassoi et al., 2006). The basis for PHS tolerance is seed dormancy, i.e., the ability of a mature seed to avoid undergoing germination, even when environmental conditions are favorable (Martynov and Dobrotvorskaya, 2012). Three genes determine the embryonic seed dormancy in wheat: $V p-1 A, V p-1 B$ and $V p$ $1 D$, which are located on the long arms of chromosomes $3 \mathrm{~A}$, $3 \mathrm{~B}$ and $3 \mathrm{D}$, respectively. Six alleles were identified at $V p-1 A$ loci, seven alleles at $V p$ - $1 B$ loci, and no polymorphism was found at $V p$ - $1 D$ loci. Therefore, high PHS tolerance is associated with $V p-1 A b, V p$ - $1 A f$ (Sun et al., 2012), $V p-1 B b$ and $V p-1 B c$ (Xia et al., 2008) alleles.

The main factors that cause PHS in wheat are the increase of hydrolytic enzymes (alpha-amylase) and the regulation of hormones of germination, i.e., abscisic acid (ABA) and gibberellic acid (GA). These hormones are related to dormancy and germination of seeds and act on the alphaamylase present in the aleurone layer. GA stimulates while ABA inhibits the embryonic germination and the formation of alpha-amylase in wheat grains (Lohwasser et al., 2013). Due to the alpha-amylase activity, starch degradation occurs in the endosperm causing degradation in the quality of baking and flour from sprouted grains, which has a low falling number (Zhang et al., 2014b).

PHS tolerance is also associated with $R$ genes controlling pericarp grain colour in wheat, i.e., genotypes with red grain colour have greater PHS tolerance than white grain genotypes. The relationship may be due to a genetic linkage between embryonic and red colour seed genes or to a pleiotropic effect of a major gene. A combination of dominant alleles $R(R-A 1, R-B 1$ and $R-D 1)$ in two or three loci had additive effects on seed dormancy (Groos et al., 2002; Martynov and Dobrotvorskaya, 2012; Zhang et al., 2014a).

Plants which are PHS tolerant are hard to select because the trait presents quantitative inheritance and, therefore, it is highly affected by environmental conditions (Fofana et al., 2009; Rasul et al., 2012). The evaluation of PHS can be achieved by measuring the percentage of grains sprouting in the ear, performed by a visual analysis and counting of sprouted grains. Also, the activity of alpha-amylase can be measured by the falling number in whole flour (Rasul et al., 2009; Zhang et al., 2014b). Both techniques are very often 
used by breeders. Combining ability measures allow the prediction of favorable alleles to increase PHS tolerance and grain yield that are present in a particular parent. Furthermore, a high heterosis obtained from hybrid combinations results in a higher probability of recovering more productive and PHS tolerant individuals in the segregant populations. Exploring the SCA in five wheat cultivars, Barnard et al. (2005) found that even a parent with low PHS tolerance can be used in specific combinations to increase PHS tolerance. The aim of this work were to evaluate the potential of Brazilian wheat combinations in generating high grain yield with pre-harvest sprouting tolerance genotypes through measures of genetic gains and $\mathrm{F}_{1}$ hybrid heterosis.

\section{Results}

\section{Analysis of variance}

The analyses of variance of parents and hybrids indicate that the GCA, SCA and the reciprocal effects were statistically significant for all traits, presuming the existence of variability between treatments. The effects of GCA are associated with additive gene actions and SCA to non-additive gene actions (dominance and epistasis). The contribution of non-additive effects on the SG, WFN and GY was estimated based on mean squares. However, the values of GCA were higher than SCA for all traits, showing greater contribution of additive gene effects for the control of PHS tolerance and grain yield in wheat.

The parents and the populations evaluated in the study showed high variability for SG, WFN and GY (Table 2). Among the parents, the highest contribution to PHS tolerance came from Frontana with reduced SG and high WFN values. Quartzo showed reduced SG, TBIO Itaipú high WFN and BRS 220 high GY. Therefore, among the most promising combinations, at least one parent with high performance is present. Marfim x Frontana and Supera x TBIO Itaipú, as well as their reciprocal combinations showed, respectively, the best SG and WFN. Combinations BRS 220 x TBIOItaipú (reciprocal, TBIOItaipú x BRS 220), BRS 220 x Quartzo and Quartzo x Frontana showed reduced SG and high GY. These results show the positive contribution of dominant alleles from Frontana, Quartzo and TBIO Itaipú for PHS tolerance and BRS 220 and Quartzo for grain yield in wheat.

\section{General and specific combining abilities}

The cultivars BRS 194 and Frontana gave the best combinations for PHS tolerance with negative GCA for the SG and positive for the WFN, contributing with additive effects for PHS tolerance (Table 3). Quartzo was featured for all traits due to its negative and positive GCA effects for the SG and WFN, respectively. Also, positive effects for GY were observed, indicating that this parent contributes with additive genes for PHS tolerance and grain yield. One of the major considerations in the selection strategy for wheat breeding programs is the proportion of additive genetic effects of a given trait (Barnard et al., 2005; Yücel et al., 2009). In wheat, the selection of promising genotypes with high GCA that contribute with complementary genes, i.e., most often dominant alleles at different loci, in order to form new populations is recommended (Yücel et al., 2011).

SCA values for the SG and WFN suggest that combinations BRS 220 x Marfim, Marfim x Frontana, Marfim x TBIO Itaipú, Supera x TBIO Itaipú, BRS 194 x Quartzo, Frontana x TBIO Itaipú, Quartzo x Supera, Quartzo x Valente, Quartzo x
BRS 194 e Quartzo x Frontana showed high SCA (Table 4). At least one parent (Supera, Marfim, BRS 194, Frontana, TBIO Itaipú and Quartzo) with high GCA is of interest to the PHS tolerance in wheat populations (Table 3). The combinations showed additive and non-additive effects contributing for PHS tolerance. Quartzo presented high GCA for all traits and was present in combinations BRS $220 \mathrm{x}$ Quartzo and Marfim x Quartzo, with negative SCA for SG and positive SCA for WFN and GY. Therefore, combinations showed additive and non-additive effects governing PHS tolerance and grain yield. The combination Supera $\mathrm{x}$ Valente showed good SCA for all traits indicating a high allelic complementarity, with non-additive effects governing PHS tolerance and grain yield. SCA analyses (Table 3) detected reciprocal effects in the combinations evaluated. The combination Supera x BRS 194 showed negative SCA for SG and WFN, however, the reciprocal combination BRS $194 \mathrm{x}$ Supera showed SCA close to zero for SG and positive for WFN.

In heterosis analysis, negative values for the SG and positive for WFN and GY are desirable in the populations, being indicative of the presence of individuals within the populations with PHS tolerance and high yield (Table 5). Thirteen combinations showed negative heterosis for SG and positive for WFN, simultaneously. Seventeen combinations showed negative heterosis for the SG and positive for WFN and GY, simultaneously (Table 6). These combinations that showed heterosis of interest have individuals with increased PHS tolerance.

\section{Discussion}

Grain yield and quality of wheat are affected by PHS, making it mandatory to generate tolerant genotypes. The significance of the mean squares of GCA and SCA for all traits indicated the existence of genotype variability, which is essential for selecting PHS tolerant genotypes (Table 1). GCA effects are associated with additive genes and SCA to non-additive (dominance and epistasis). In this study, genes of additive and non-additive effects were found, evidencing a greater contribution of additive gene action controlling PHS tolerance and grain yield in wheat. Additive gene effects are easily passed to progenies and continue with the advancement of generations until they reach homozygosity, determining narrow sense heritability. This is an important parameter in self-pollinating species such as wheat (Ribeiro et al., 2011). The genotypes that presented lower SG and high WFN were considered high dormancy seeds and PHS tolerant genotypes (Table 1). The genotypes were influenced by the expression of maternal effects of extra chromosomal inheritance or interaction between nuclear and organellar genes. Therefore, there were differences in genotypes when used as male or female parents to the traits SG, WFN and GY in wheat (Barnard et al., 2005; Yücel et al., 2011).

The application of wheat flour in products is limited due to PHS, resulting in major financial losses for industries and farmers (Yücel et al., 2011). Most PHS tolerance in wheat is directly associated to the rate of water uptake, dormancy level of seeds and ability to mobilize reserves during germination (Rathjen et al., 2009; Emebiri et al., 2010; Nonogaki et al., 2010; Martynov and Dobrotvorskaya, 2012; Lohwasser et al., 2013; Bi et al., 2014; Chen et al., 2014; Zhang et al., 2014a). Thus, the multiple factors involved highlight the difficulty of selecting plants with PHS tolerance, therefore the character is inherited quantitatively and strongly affected by environmental conditions (Barnard 
Table 1. Summary of the analysis of variance of traits in diallel experiment involving the parents and hybrid combinations of wheat.

\begin{tabular}{|c|c|c|c|c|}
\hline \multirow{2}{*}{ Source of variation } & \multicolumn{4}{|c|}{ Mean Square } \\
\hline & $\mathrm{DF}$ & SG (\%) & WFN (s) & GY (g) \\
\hline Trataments & 63 & $589.24^{* *}$ & $35047.57^{* *}$ & $60.86^{* * *}$ \\
\hline GCA & 7 & $1700.36^{*}$ & $146567.72^{* * *}$ & $169.23^{*}$ \\
\hline SCA & 28 & $719.70^{* *}$ & $36623.46^{* *}$ & $65.31^{* *}$ \\
\hline $\mathrm{RE}$ & 28 & $180.99^{* *}$ & $3591.63^{* *}$ & $29.32^{* *}$ \\
\hline Resídue & 126 & 4.52 & 212.20 & 7.20 \\
\hline C. V. (\%) & - & 16.09 & 4.34 & 11.04 \\
\hline
\end{tabular}

Table 2. Mean comparison for traits related to pre-harvest sprouting and grain yield in parents (in diagonal) and hybrid combinations of wheat.

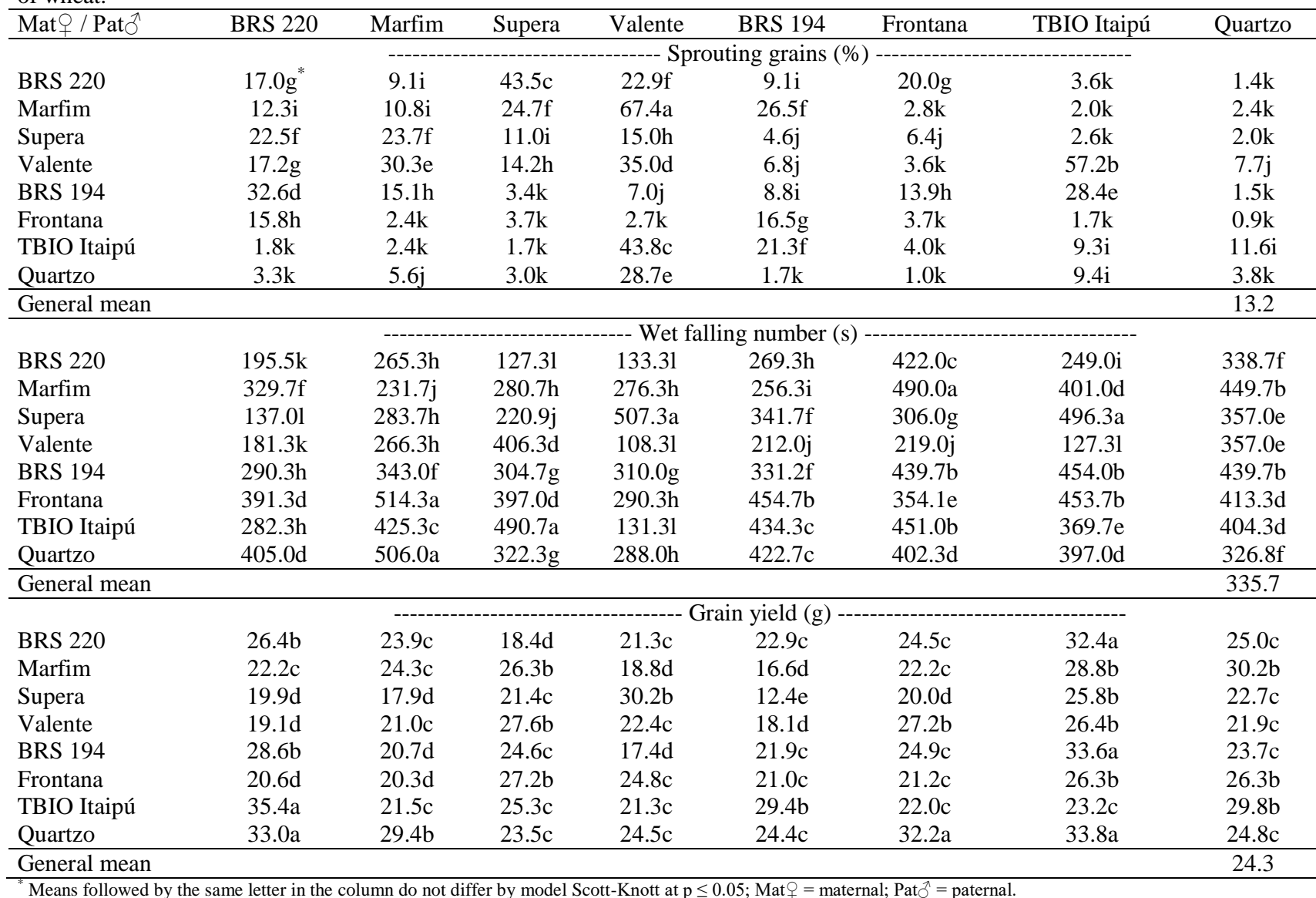

Table 3. General combining ability of eight elite wheat cultivars for traits related to pre-harvest sprouting and grain yield.

\begin{tabular}{llll}
\hline \multirow{2}{*}{ Parents } & \multicolumn{2}{l}{ Traits evaluated } & GY $(\mathrm{g})$ \\
\cline { 2 - 4 } & SG $(\%)$ & WFN $(\mathrm{s})$ & 0.64 \\
BRS 220 & 2.40 & -72.28 & -1.32 \\
Marfim & 2.06 & 11.18 & -1.25 \\
Supera & -1.09 & -10.71 & -1.72 \\
Valente & 11.53 & -90.61 & -1.35 \\
BRS 194 & -0.53 & 16.61 & -0.58 \\
Frontana & -6.73 & 61.20 & 3.12 \\
TBIO Itaipú & 0.00 & 35.25 & 2.48 \\
Quartzo & -7.64 & 49.36 & 0.36 \\
\hline SD $\left(g_{i}\right)^{*}$ & 0.29 & 1.97 & 0.55 \\
SD $\left(g_{i} g_{j}\right)^{+}$ & 0.43 & 2.97 & \\
\hline Standard deviation of the estimate $g_{i \cdot}{ }^{+}$Standard deviation of the difference between $g_{i}$ and $g_{j}$ SG $=$ sprouted grains; WFN= wet falling number; GY= grain yield per \\
plant.
\end{tabular}


Table 4. Specific combining ability (upper diagonal), considering the reciprocal effect (lower diagonal) of eight parents (in diagonal) and 28 wheat combinations for PHS tolerance and grain yield related traits.

\begin{tabular}{|c|c|c|c|c|c|c|c|c|}
\hline Parents & BRS 220 & Marfim & Supera & Valente & BRS 194 & Frontana & TBIO Itaipú & Quartzo \\
\hline & \multicolumn{8}{|c|}{ - Sprouting grains $(\%)$ - } \\
\hline BRS 220 & -1.10 & -6.91 & 18.53 & -7.05 & 5.84 & 9.11 & -12.85 & -5.56 \\
\hline Marfim & -1.60 & -6.95 & 9.90 & 22.09 & 4.40 & -5.89 & -13.06 & -3.57 \\
\hline Supera & 10.47 & 0.33 & 0.37 & -9.01 & -7.60 & -0.32 & -9.96 & -1.91 \\
\hline Valente & 2.87 & 18.60 & 0.44 & -0.95 & -17.27 & -14.84 & 25.84 & 1.19 \\
\hline BRS 194 & -11.78 & 7.38 & 0.60 & -0.11 & -3.25 & 9.10 & 12.20 & -3.41 \\
\hline Frontana & 2.15 & 0.22 & 1.31 & 0.49 & -1.49 & 4.28 & -3.57 & 2.14 \\
\hline TBIO Itaipú & 0.91 & -0.19 & 0.45 & 6.72 & 3.56 & -1.18 & -3.75 & 5.16 \\
\hline \multirow[t]{2}{*}{ Quartzo } & -0.93 & -1.58 & -0.49 & -10.50 & -0.10 & -0.07 & 1.31 & 5.96 \\
\hline & \multicolumn{8}{|c|}{--or } \\
\hline BRS 220 & 4.80 & 22.96 & -120.48 & -15.42 & -0.14 & 82.10 & -32.94 & 59.12 \\
\hline Marfim & -32.17 & -127.25 & -53.94 & 15.11 & -63.77 & 94.14 & 31.09 & 81.65 \\
\hline Supera & -4.84 & -1.50 & -93.78 & 222.51 & -18.37 & -34.63 & 133.32 & -34.62 \\
\hline Valente & -24.00 & 5.00 & 50.50 & -47.12 & -0.64 & -51.58 & -150.96 & 28.11 \\
\hline BRS 194 & -10.50 & -43.34 & 18.50 & -49.00 & -37.03 & 33.72 & 56.67 & 29.56 \\
\hline Frontana & 15.34 & -12.17 & -45.50 & -35.67 & -7.50 & -105.61 & 20.24 & -38.37 \\
\hline TBIO Itaipú & -16.67 & -12.17 & 2.83 & -2.00 & 9.84 & 1.34 & -37.83 & -19.58 \\
\hline \multirow[t]{2}{*}{ Quartzo } & -33.17 & -28.17 & 17.34 & 34.50 & 8.50 & 5.50 & 3.67 & -105.86 \\
\hline & \multicolumn{8}{|c|}{ 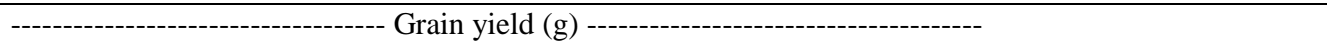 } \\
\hline BRS 220 & 1.01 & -0.53 & -4.50 & -3.10 & 1.99 & -1.99 & 5.72 & 1.40 \\
\hline Marfim & 0.94 & 2.69 & 0.35 & -1.53 & -3.06 & -1.25 & -1.04 & 4.38 \\
\hline Supera & -0.55 & 4.30 & -0.96 & 7.39 & -0.28 & 1.04 & -0.48 & -2.56 \\
\hline Valente & 1.17 & -1.08 & 1.31 & 0.92 & -3.48 & 3.73 & -2.00 & -1.94 \\
\hline BRS 194 & -2.87 & -2.23 & -3.07 & 0.39 & -0.13 & 0.49 & 6.01 & -1.54 \\
\hline Frontana & 1.97 & 0.90 & -3.70 & 1.18 & 1.92 & -2.44 & -2.63 & 3.05 \\
\hline TBIO Itaipú & -1.51 & 3.58 & 0.24 & 2.55 & 2.91 & 2.31 & -7.26 & 1.68 \\
\hline Quartzo & -3.99 & 0.50 & -0.34 & -1.24 & -0.32 & -3.03 & -2.10 & -4.46 \\
\hline
\end{tabular}

Table 5. Estimation (\%) of heterosis (upper diagonal), considering the reciprocal combination (lower diagonal) compared to parental average, evaluated in 56 wheat hybrids.

\begin{tabular}{|c|c|c|c|c|c|c|c|c|}
\hline Parents & BRS 220 & Marfim & Supera & Valente & BRS 194 & Frontana & TBIO Itaipú & Quartzo \\
\hline & --- & --------- & -- Sprout & grains $(\%)$ & & & & \\
\hline BRS 220 & - & -34.61 & 210.85 & -11.74 & -29.46 & 92.61 & -72.41 & -86.20 \\
\hline Marfim & -11.38 & - & 126.61 & 194.47 & 169.61 & -61.10 & -80.17 & -66.67 \\
\hline Supera & 61.14 & 117.74 & - & -34.54 & -53.79 & -12.93 & -74.71 & -72.40 \\
\hline Valente & -33.93 & 32.17 & -38.32 & - & -69.08 & -81.22 & 158.39 & -60.07 \\
\hline BRS 194 & 152.97 & 53.48 & -65.94 & -68.01 & - & 121.28 & 213.24 & -76.66 \\
\hline Frontana & 52.73 & -67.05 & -49.66 & -86.22 & 163.83 & - & -73.98 & -76.89 \\
\hline TBIO Itaipú & -86.58 & -76.53 & -83.58 & 97.89 & 134.93 & -38.27 & - & 77.10 \\
\hline \multirow[t]{2}{*}{ Quartzo } & -68.22 & -23.29 & -58.82 & 48.36 & -73.47 & -73.33 & 43.00 & - \\
\hline & -- & - & Wet falli & lumber $(\mathrm{s})$ & -1----- & --------- & & \\
\hline BRS 220 & - & 24.22 & -38.84 & -12.23 & 2.28 & 53.58 & -11.89 & 29.67 \\
\hline Marfim & 54.34 & - & 24.02 & 62.53 & -8.92 & 67.30 & 33.35 & 61.02 \\
\hline Supera & -34.20 & 25.35 & - & 208.19 & 23.78 & 6.44 & 68.07 & 30.36 \\
\hline Valente & 19.36 & 56.65 & 146.84 & - & -3.53 & -5.28 & -46.73 & 64.08 \\
\hline BRS 194 & 10.25 & 21.88 & 10.37 & 41.07 & - & 28.33 & 29.55 & 33.64 \\
\hline Frontana & 42.42 & 75.61 & 38.09 & 25.58 & 32.70 & - & 25.36 & 21.41 \\
\hline TBIO Itaipú & -0.10 & 41.44 & 66.15 & -45.06 & 23.94 & 24.62 & - & 16.09 \\
\hline \multirow[t]{2}{*}{ Quartzo } & 55.07 & 81.19 & 17.70 & 32.36 & 28.47 & 18.18 & 13.99 & - \\
\hline & ------ & ------ & ---- Grail & eld $(\mathrm{g})$ - & ----- & -------- & & \\
\hline BRS 220 & - & -5.53 & -22.87 & -12.84 & -5.25 & 3.09 & 30.65 & -2.28 \\
\hline Marfim & -12.24 & - & 15.01 & -19.40 & -28.28 & -2.35 & 21.32 & 23.01 \\
\hline Supera & -16.60 & -21.57 & - & 37.69 & -42.77 & -6.26 & 15.52 & -1.95 \\
\hline Valente & -21.58 & -10.27 & 25.68 & - & -18.20 & 24.62 & 15.62 & -7.27 \\
\hline BRS 194 & 18.65 & -10.39 & 13.69 & -21.35 & - & 15.79 & 48.89 & 1.64 \\
\hline Frontana & -13.46 & -10.70 & 27.70 & 13.91 & -2.48 & - & 18.47 & 14.43 \\
\hline TBIO Itaipú & 42.88 & -9.40 & 13.43 & -6.72 & 30.13 & -0.75 & - & 23.94 \\
\hline Quartzo & 28.86 & 19.76 & 1.66 & 3.88 & 4.35 & 40.10 & 40.74 & - \\
\hline
\end{tabular}


Table 6. Promising combinations for developing wheat segregant populations with PHS tolerant individuals.

\begin{tabular}{|c|c|c|c|}
\hline \multirow{2}{*}{ Progeny } & \multicolumn{3}{|l|}{ Heterosis } \\
\hline & SG (\%) & WFN (s) & GY $(g)$ \\
\hline BRS 220 x Marfim & Negative & Positive & - \\
\hline BRS 220 x BRS 194 & Negative & Positive & - \\
\hline BRS 220 x Quartzo & Negative & Positive & - \\
\hline Marfim x Frontana & Negative & Positive & - \\
\hline Marfim x BRS 220 & Negative & Positive & - \\
\hline Supera x BRS 194 & Negative & Positive & - \\
\hline Supera $\mathrm{x}$ Frontana & Negative & Positive & - \\
\hline Supera x Quartzo & Negative & Positive & - \\
\hline TBIO Itaipú x Marfim & Negative & Positive & - \\
\hline TBIO Itaipú x Frontana & Negative & Positive & - \\
\hline Valente x Quartzo & Negative & Positive & - \\
\hline Frontana x Marfim & Negative & Positive & - \\
\hline BRS 194 x Valente & Negative & Positive & - \\
\hline Marfim x TBIO Itaipú & Negative & Positive & Positive \\
\hline Marfim x Quartzo & Negative & Positive & Positive \\
\hline Supera $x$ Valente & Negative & Positive & Positive \\
\hline Supera x TBIO Itaipú & Negative & Positive & Positive \\
\hline Frontana x TBIO Itaipú & Negative & Positive & Positive \\
\hline Frontana x Quartzo & Negative & Positive & Positive \\
\hline Frontana x Supera & Negative & Positive & Positive \\
\hline Frontana $\mathrm{x}$ Valente & Negative & Positive & Positive \\
\hline Quartzo x BRS 194 & Negative & Positive & Positive \\
\hline Quartzo x BRS 220 & Negative & Positive & Positive \\
\hline Quartzo x Marfim & Negative & Positive & Positive \\
\hline Quartzo x Supera & Negative & Positive & Positive \\
\hline Quartzo x Frontana & Negative & Positive & Positive \\
\hline BRS 194 x Supera & Negative & Positive & Positive \\
\hline BRS 194 x Quartzo & Negative & Positive & Positive \\
\hline Valente x Supera & Negative & Positive & Positive \\
\hline TBIO Itaipú x Supera & Negative & Positive & Positive \\
\hline
\end{tabular}

$\mathrm{SG}=$ sprouted grains; $\mathrm{WFN}=$ wet falling number; $\mathrm{GY}=$ grain yield per plant

et al., 2005; Bassoi et al., 2006; Fofana et al., 2009; Rasul et al., 2012). The colour of the tegument in wheat grains is associated with PHS tolerance, where a white colour indicates higher PHS sensitivity when compared to red grains. This association may be due to pleiotropic effects of genes controlling the colour of the grains or by binding genetic diversity among pigmentation genes and those affecting PHS. However, the mechanism of action of the tegument colour gene was not clearly described (Gross et al., 2002; Bi et al., 2014). Dormancy is related to the presence of germination hormones where ABA inhibits and GA stimulates the formation of alpha-amylase present in the aleurone layer, in wheat seed germination process (Lohwasser et al., 2013).

The SG is considered a classic measure of PHS tolerance and wheat grain dormancy levels. The highest values of germination indicate grains with less accumulated dormancy, thus characterizing a germination process at an advanced level (Gelin et al., 2007; Rasul et al., 2012). Another measure of PHS tolerance is the falling number, a measure of alphaamylase enzyme activity in whole flour (Mrva et al., 2009; Gooding et al., 2012; Zhang et al., 2014b). The WFN may indicate genotypes with PHS tolerance when in situations of relatively low rainfall. The evaluation of the falling number is performed in the flour and thus can measure the germination process, although there has been no visual seed germination. In falling number analysis, the values express the activity of the alpha-amylase enzyme as a function of time, thus, higher values indicate a lower enzyme activity in the sample analyzed (Hagberg, 1960; Fofana et al., 2009; Zhang et al., 2014b).
The analysis of combining ability allows one to evaluate a number of $F_{1}$ hybrids, and based on combining ability of the parents and the average performance of $\mathrm{F}_{1}$ hybrids, to concentrate efforts on the most promising combinations (Ribeiro et al., 2011). Some hybrid combinations can show strong effect of organellar genes in the two traits related to PHS tolerance (Yücel et al., 2011). Others studies have shown that traits associated with PHS in wheat are governed by additive gene action (Jiang and Xiao, 2005; Yücel et al., 2011; Ghanbari and Mir, 2013), but minor non-additive gene action (dominance and epistasis) are also detected.

The combinations showing better SCA can present transgressive segregants for PHS tolerance and grain yield in wheat. The PHS sensitivity is determined by genetic factors and environmental conditions encountered during seed development. Local genotypes (Brazilian) of wheat can be used as good sources of PHS tolerance and development of new cultivars with seed dormancy and greater PHS tolerance in wheat breeding programs.

The combinations that showed, simultaneously, heterosis of interest for the traits SG, WFN and GY have positive transgressive segregating genotypes, which may be selected to promote increased PHS tolerance and grain yield in wheat. Since wheat is a self-pollinated species, breeders concentrate efforts in additive gene effects, due to ease of transmitting the trait to the progenies and trait stability in advanced generations. Therefore, high heterosis for PHS tolerance and grain yield traits, when maintained in advanced generations, can lead to superior genotypes, due to higher frequency of dominant complementary genes in these progenies.

Identification of Quantitative Trait Loci (QTLs) responsible for dormancy and PHS tolerance in wheat can help the 
breeding for PHS tolerance. In wheat mapping studies, the genetic control of PHS tolerance was found to be quantitative (multigenic). The identification of QTLs in traits that quantify PHS tolerance as falling number, alpha-amylase enzyme activity, grain seed coat coloring ( $R$ genes), index and percentage of sprouted grains (Ogbonnaya et al., 2008; Fofana et al., 2009; Kumar et al., 2009; Rasul et al., 2009; Lohwasser et al., 2013; Zhang et al., 2014b) can lead to more successful attempts. Thirteen QTLs were identifing associated with falling number and some of them showed chromosomal locations similar to previously reported QTLs associated with PHS tolerance in wheat. Still, six major QTLs cumulatively explained up to $45 \%$ of the variation for falling number, and have been suggested for use in marker-assisted selection for high falling number plants in wheat breeding programs (Zhang et al., 2014b).

For wheat grain colour, two QTLs for PHS tolerance and two microsatellite markers linked to the main QTL for PHS tolerance were found, and these markers showed strong associations with seed dormancy and PHS tolerance in a white colour wheat variety. Also, these two microsatellite markers may be used in marker-assisted selection to incorporate QTLs responsible for the PHS tolerance in genotypes with white grains sensitive to PHS (Ogbonnaya et al., 2008). Furthermore, two QTLs were identified for falling number and five for the germination index in wheat. Thus, the germination index may indicate that more genes are involved in PHS process than WFN, possibly because the germination index measures a more developed stage in germination (Rasul et al., 2009).

\section{Materials and Methods}

\section{Plant material}

Eight elite cultivars of wheat developed by leading breeding programs in Brazil were used to obtain $56 \mathrm{~F}_{1}$ hybrid combinations. Artificial crosses were performed in 2010, in a greenhouse, following a complete diallel model considering the reciprocals. The genotypes used in the crosses were: Marfim, Supera, Valente and Quartzo (developed jointly by Biotrigo Genética Ltda and OR Melhoramento de Sementes Ltda companies); TBIO Itaipú (Biotrigo Genética Ltda); BRS 220 and BRS 194 (Empresa Brasileira de Pesquisa Agropecuária) and Frontana (State of Rio Grande do Sul Agricultural Experimental Station at Veranópolis). Frontana, which is a Brazilian cultivar released in 1940, was included because it represents the greatest contribution of the Brazilian breeding for wheat in the world, considering its leaf rust resistance, natural threshing and pre-harvest sprouting tolerance. The parents were chosen because of the contrasting phenotype for PHS tolerance. BRS 220, Marfim, Supera and Valente are sensitive and BRS 194, Frontana, TBIO Itaipú and Quartzo are tolerant to PHS.

\section{Experimental and environmental conditions}

The experiment was conducted in July 2011 in an experimental field located at the county of Capão do Leão, Rio Grande do Sul. The county is situated $31^{\circ} 52^{\prime} 00^{\prime \prime}$ South latitude and $52^{\circ} 21^{\prime} 24^{\prime \prime}$ West longitude, with an altitude of $13.24 \mathrm{~m}$ and average annual rainfall of $1280.2 \mathrm{~mm}$. Eight parents and $56 \mathrm{~F}_{1}$ hybrids were sowed as spaced plants, grown in $3 \mathrm{~m}$ long rows, spaced $0.3 \mathrm{~m}$ of distance in a randomized block design with three replications, where each plant was considered one unit of observation. Two fungicide applications of Folicur (Tebuconazole) were performed in the growing season. The fertilization, sowing density, weed control and pests were performed in accordance with the Recommendations of the Brazilian Commission of Wheat and Triticale Research.

\section{Character assessment}

The ears were harvested at physiological maturity and dried at room temperature for seven days in a protected location, then placed in plastic bags and stored in a freezer at temperatures around $-20{ }^{\circ} \mathrm{C}$ to maintain seed dormancy. For characterizing PHS tolerance, the SG and WFN were analyzed. The ears of parents and $F_{1}$ hybrids used in the analysis of the SG were sampled in all plants of the experiment. The SG analyses were conducted in a randomized block design with three replications, with each replicate consisting of five ears. The ears were immersed in distilled water for $8 \mathrm{~h}$ and placed on paper towel to remove excessive water. The ears were treated with fungicide Vitavax-Thiram [Active Ingredient (carboxin + thiram): 200 $+200 \mathrm{~g} \mathrm{~L}^{-1}$ ] recommended by the manufacturer. Later, they were rolled in vertical position in germination paper, previously soaked in distilled water and placed in plastic bags to avoid moisture loss. After, the ears were incubated for seven days at $25^{\circ} \mathrm{C} \pm 1{ }^{\circ} \mathrm{C}$ in a growth chamber type BOD. After seven days of incubation, the rolls were removed from the growth chamber and placed to dry in a kiln at $50{ }^{\circ} \mathrm{C}$ for $72 \mathrm{~h}$. After this period, the number of sprouted grains per ear was evaluated.

The ears of parents and $F_{1}$ hybrids used in the analysis of WFN were sampled in all plants of the experiment. The WFN analysis consisted in a germination test, under a randomized block design with three replications, each replicate consisting of 20 ears. The ears were immersed in distilled water for $2 \mathrm{~h}$, and then placed on paper towels to remove excessive water. Later they were treated with fungicide Vitavax-Thiram [Active Ingredient (carboxin + thiram): $200+200 \mathrm{~g} \mathrm{~L}^{-1}$ ] recommended by the manufacturer. The ear were rolled in the vertical position in germination paper, previously soaked in distilled water and placed in plastic bags to avoid moisture loss. After, they were incubated for seven days at $25^{\circ} \mathrm{C} \pm 1$ ${ }^{\circ} \mathrm{C}$ in a growth chamber type BOD. After three days of incubation the rolls with the ears were removed from the growth chamber and placed to dry in a kiln at $50{ }^{\circ} \mathrm{C}$ for $72 \mathrm{~h}$. In evaluating the falling number, ears were threshed and subsequently milled in a Perten mill (model Laboratory Mill 3100 , Perten Instruments). The WFN was determined according to the method $56-81 \mathrm{~B}$ (AACC, 2000), in an instrument Perten Falling Number 1500 (Perten Instruments), using whole flour. Representative samples of $7 \mathrm{~g}$ of flour were placed in test tubes specific for falling number; samples of $25 \mathrm{~mL}$ of distilled water were added to form the dough. Before being placed in the machine, the tube containing the suspension was stirred until no dry flour was seen at the bottom of the tube. During the initial period of $60 \mathrm{~s}$, the apparatus of the plunger was moved up and down inside the tube to ensure uniform heating and mixing of the dough. The time required for the plunger to fall from the top to the bottom of the tube determines the falling number in seconds. The value expressed in seconds represents that the shorter fall time, the greater the content and the activity of the enzyme. Grain yield of each parental and $F_{1}$ hybrid plant of the experiment was evaluated and considered an observation unit. Plants were harvested at crop maturation and were threshed individually in the laboratory to determine the GY (in grams). 


\section{Statistical analysis}

The data were subjected to analyses of variance, being the sum squares of treatments decomposed into GCA, SCA and reciprocal effects. The method 1 of the fixed model of Griffing (1956) was used, according to the statistical model: $Y_{i j}=m+g_{i}+g_{j}+s_{i j}+r_{i j}+\varepsilon_{i j}$, where the $Y_{i j}$ : average value of the hybrid combination $(i \neq j)$ or of the parent $(i=j) ; m$ : general mean; $g_{i}$ and $g_{j}$ : effects of general combining ability of the $i$-th and $j$-th parent, respectively; $s_{i j}$ : effect of specific combining ability for the crossings between the ordered parents $i$ and $j ; r_{i j}$ : reciprocal effect which measures the differences provided by the parent $i$ or $j$ when used as a pollen donor or receiver; $\varepsilon_{i j}$ : average experimental error. Statistical analyzes were performed using statistical software Genes (Cruz, 2013).

The estimation of heterosis was performed according to the model: $\mathrm{H} 1(\%)=[(\overline{\mathrm{F} 1}-\overline{\mathrm{MP}}) / \overline{\mathrm{MP}}] * 100$, where $\mathrm{H} 1=$ heterosis compared to the mean of the parents, $\mathrm{F} 1=$ mean hybrid and MP = mean of the parents, i.e., [(P1 + P2)/2]. The heretosis model was proposed and described by Gardner and Eberhart (1966).

\section{Conclusions}

PHS tolerance of Brazilian wheat genotypes analysed by SG and WFN is governed by additive and non-additive genes, and reciprocal effects were detected in some combinations. BRS 194, Frontana and Quartzo contribute with additive and non-additive genes for PHS in wheat. In addition, Quartzo contributes with additive and non-additive genes to increase grain yield. Wheat combinations containing BRS 194, Frontana and Quartzo indicate better chances of selecting high yield genotypes with pre-harvest sprouting tolerance.

\section{Acknowledgements}

The authors wish to acknowledge the CNPq, CAPES, FAPERGS, UFPel and UNIJUÍ for providing financial and facility support, scholarships for students and research productivity fellowships.

\section{References}

AACC (2000) Approved methods of the American Association of Cereal Chemists. 10th ed. American Assoc. Cereal Chemists, St. Paul, MN.

Barnard A, Van Deventer CS, Maartens H (2005) Genetic variability of preharvest sprouting - the South African situation. Euphytica. 143:291-296.

Bassoi MC, Flintham J, Riede CR (2006) Analysis of preharvest sprouting in three Brazilian wheat populations. Pesqui Agropecu Bras. 41:583-590.

Bi HH, Sun YW, Xiau YG, Xia LQ (2014) Characterization of DFR allelic variations and their associations with preharvest sprouting resistance in a set of red-grained Chinese wheat germplasm. Euphytica. 195:197-207.

Chen J, Chen H, Wang X, Yu C, Wang C, Zhu D (2014) The characteristic of hyperspectral image of wheat seeds during sprouting. Int Fed Info Proc. 419:408-421.

Cruz CD (2013) GENES - a software package for analysis in experimental statistics and quantitative genetics. Acta Sci. 35:271-276.

Emebiri LC, Oliver JR, Mrva KD, Mares D (2010) Association mapping of late maturity $\alpha$-amylase (LMA) activity in a collection of synthetic hexaploid wheat. Mol Breeding. 26:39-49.

Fofana B, Humphreys DG, Rasul G, Cloutier S, Brûlé-Babel A, Woods S, Somers DJ (2009) Mapping quantitative trait loci controlling pre-harvest sprouting resistance in a red $\mathrm{x}$ white seeded spring wheat cross. Euphytica. 165:509-521.

Gardner CO, Eberhart SA (1966) Analysis and interpretation of the variety cross diallel and related populations. Biometrics. 22:439-452.

Gelin JR, Elias EM, Manthey FA, Grant L (2007) Study of the relationship between sprouting score and sprout damage in durum wheat (Triticum turgidum L. var. durum). Cereal Res Commun. 35:53-61.

Ghanbari M, Mir B (2013) Genetic analysis of pre-harvest sprouting resistance in wheat cultivars (Triticum aestivum L.). Intl J Agron Plant Prod. 4:2260-2266.

Gooding MJ, Uppal RK, Addisu M, Harris KD, Uauy C, Simmonds JR, Murdoch AJ (2012) Reduced height alleles $(R h t)$ and Hagberg falling number of wheat. J Cereal Sci. 55:305-311.

Griffing B (1956) Concept of general and specific combining ability in relation to diallel crossing systems. Aust J Biol Sci. 9:462-493.

Groos C, Gay G, Perretant MR, Gervais L, Bernard M, Dedryver F, Charmet G (2002) Study of the relationship between preharvest sprouting and grain color by quantitative trait loci analysis in a white $\mathrm{x}$ red grain breadwheat cross. Theor Appl Genet. 104:39-47.

Hagberg SA (1960) Rapid method for determination alphaamylase activity. Cereal Chem. 38:218-222.

Jiang GL, Xiao S (2005) Factorial cross analysis of preharvest sprouting resistance in white wheat. Field Crop Res. 91:63-69.

Kulwal P, Ishikawa G, Benscher D, Feng Z, Yu LX, Jadhav A, Sorrells ME (2012) Association mapping for pre-harvest sprouting resistance in white winter wheat. Theor Appl Genet. 125:793-805.

Kumar A, Kumar J, Singh R, Garg T, Chhuneja P, Balyan HS, Gupta PK (2009) QTL analysis for grain colour and pre-harvest sprouting in bread wheat. Plant Sci. 177:114122.

Lohwasser U, Rehman Arif MA, Börner A (2013) Discovery of loci determining pre-harvest sprouting and dormancy in wheat and barley applying segregation and association mapping. Biol Plantarum. 57:663-674.

Martynov SP, Dobrotvorskaya TV (2012) Resistance of bread wheat (Triticum aestivum L.) to preharvest sprouting: an association analysis. Russ J Genet. 48:975-984.

Mrva K, Cheong J, Yu B, Law HY, Mares D (2009) Late maturity $\alpha$-amylase in synthetic hexaploid wheat. Euphytica. 168:403-411.

Nonogaki H, Bassel GW, Bewley JD (2010) Germination still a mystery. Plant Sci. 179:574-581.

Ogbonnaya FC, Imtiaz M, Ye G, Hearnden PR, Hernandez E, Eastwood RF, Winchester JM (2008) Genetic and QTL analyses of seed dormancy and preharvest sprouting resistance in the wheat germplasm CN10955. Theor Appl Genet. 116:891-902.

Rasul G, Humphreys DG, Brûlé-Babel A, Mccartney C, Knox RE, Depauw RM, Somers DJ (2009) Mapping QTLs for pre-harvest sprouting traits in the spring wheat cross 'RL4452/AC Domain'. Euphytica. 168:363-378.

Rasul G, Humphreys GD, Wu J, Brûlé-Babel A, Fofana B, Glover KD (2012) Evaluation of preharvest sprouting traits in a collection of spring wheat germplasm using genotype and genotype environment interaction model. Plant Breeding. 131:244-251. 
Rathjen JR, Strounina EV, Mares DJ (2009) Water movement into dormant and non-dormant wheat (Triticum aestivum L.) grains. J Exp Bot. 60:1619-1631.

Ribeiro G, Silveira G, Crestani M, Nornberg R, Luche HS, Mezzalira I, Oliveira AC (2011) Diallel analysis in white oat cultivars subjected to water stress. Crop Breed Appl Biot. 11:125-132.

Sun YW, Jones HD, Yang Y, Dreisigacker S, Li SM, Chen XM, Xia LQ (2012) Haplotype analysis of Viviparous-1 gene in CIMMYT elite bread wheat germplasm. Euphytica. 186:25-43.

Yücel C, Baloch FS, Özkan H (2009) Genetic analysis of some physical properties of bread wheat grain (Triticum aestivum L. em Thell). Turk J Agric For. 33:525-535.

Yücel C, Baloch FS, Hatipoglu R, Özkan H (2011) Genetic analysis of preharvest sprouting tolerance in bread wheat (Triticum aestivum L. emend. Thell.). Turk J Agric For. 35:9-22.
Xia LQ, Ganal MW, Shewry PR, He ZH, Yang Y, Röder MS (2008) Exploiting the diversity of Viviparous 1 gene associated with pre-harvest sprouting tolerance in European wheat varieties. Euphytica. 159:411-417.

Zhang Y, Miao X, Xia X, He Z (2014a) Cloning of seed dormancy genes $(T a S d r)$ associated with tolerance to preharvest sprouting in common wheat and development of a functional marker. Theor Appl Genet. 27:855-866.

Zhang J, Chen J, Bowman BC, O'Brien K, Marshall JM, Bonman JM (2014b) Association mapping of Hagberg falling number in hard white spring wheat. Crop Sci. 54:1243-1252. 